\title{
Historic development of heavy metal contamination into the Firth of Thames, New Zealand
}

\author{
S. Boehnert ${ }^{1}$ (D) $\cdot$ S. Ruiz Soto ${ }^{1} \cdot$ B. R. S. Fox ${ }^{2,3} \cdot$ Y. Yokoyama $^{4} \cdot$ D. Hebbeln ${ }^{1}$
}

Received: 31 January 2019 / Accepted: 23 September 2019 / Published online: 27 November 2019

(C) The Author(s) 2019

\begin{abstract}
Near-coastal marine sediments often provide high-resolution records of various anthropogenic influences such as the release of heavy metals, which pose a potentially negative influence on aquatic ecosystems because of their toxicity and persistence. In places, the gradual onset of man-made heavy metal emission dates back to $~ 4500$ years BP and is difficult to distinguish from potential natural sources. New Zealand offers a perfect setting for studies on anthropogenic impact due to its well-defined threestep development: pre-human era (until 1300 CE), Polynesian era ( 1300-1800 CE) and European era (since $\sim 1840 \mathrm{CE}$ ). However, hardly any information exists about the degree of heavy metal input to New Zealand's coastal areas and the 'pristine' natural background values. This study determines the natural background contents of lead $(\mathrm{Pb})$ and zinc $(\mathrm{Zn})$ in marine sediments of the Firth of Thames, a shallow marine embayment on New Zealand's North Island, and investigates anthropogenic inputs in historic times. Eight sediment cores were analysed by X-ray fluorescence (XRF) for their element composition and temporally resolved by a pollen and radiocarbon-based stratigraphic framework. Sharp increases in $\mathrm{Pb}$ and $\mathrm{Zn}$ contents occurred simultaneously with the onset of goldmining activities $(1867 \mathrm{CE})$ in the nearby catchment area. The contents of $\mathrm{Zn}(\mathrm{Pb})$ increase from very stable values around $60(13) \mathrm{ppm}$ in the older sediments, interpreted to reflect the natural background values, to an average maximum of 160 (60) ppm near the core top, interpreted to reflect a significant anthropogenic input. These findings unravel the history of contamination in the Firth of Thames and provide an urgently needed database for the assessment of its current ecological state.
\end{abstract}

Keywords Firth of Thames $\cdot$ New Zealand $\cdot$ Heavy metals $\cdot$ Zinc $\cdot$ Lead

\section{Introduction}

Anthropogenic influences on coastal marine ecosystems can date back several centuries or even millennia, however, with severely increasing impacts during the last two centuries. Often this is accompanied by the rising release of various pollutants into the environment. A prominent example is the

S. Boehnert

sboehnert@marum.de

1 MARUM - Centre for Marine Environmental Sciences, University of Bremen, Leobener Straße 8, 28359 Bremen, Germany

2 Department of Biological and Geographical Sciences, University of Huddersfield, Queensgate, Huddersfield HD1 3DH, UK

3 School of Science, University of Waikato, Private Bag 3105, Hamilton 3240, New Zealand

4 Atmosphere and Ocean Research Institute, The University of Tokyo, 5-1-5 Kashiwanoha, Kashiwa, Chiba 277-8564, Japan increasing release of heavy metals by mining and metallurgy, with the beginning traced back to the Copper and Early Bronze Age $\sim 4500$ years BP (e.g. Leblanc et al. 2000). To understand the sources, the causes and the temporal development of enhanced inputs of contaminants, such as heavy metals, to the marine environment, near-coastal sediment depocentres can provide high-resolution sedimentary archives. These have a great potential for the reconstruction of heavy metal inputs through time and to differentiate between anthropogenic or natural causes.

Pollution history recorded in marine sediments (e.g. Irion et al. 1987; Fukue et al. 1999; Hebbeln et al. 2003; Badr et al. 2009; Seshan et al. 2010) has been decoded from many places in the world. However, only a few studies exist about anthropogenic heavy metal enrichments in sediments from New Zealand. These are mainly concerned with streams (Webster 1995; Craw and Chappell 2000; Sheppard et al. 2009; Clement et al. 2017) and more recent releases by urban runoff near major cities (Dickinson et al. 1996; Abrahim and Parker 2002, 2008). 
New Zealand offers an exceptional setting to study the historical development of human impact, as it was the last main landmass that was colonised by people (e.g. McGlone et al. 1994). Three different stages can be distinguished: (i) the pre-human era until $\sim 1300 \mathrm{CE}$, with pristine flora and fauna influenced by volcanic activity and natural wildfires, followed by (ii) the Polynesian era with first human settlements and slash-and-burn deforestation starting $1300 \mathrm{CE}$ (e.g. McFadgen 1994; Ogden et al. 1998; McGlone and Wilmshurst 1999; Horrocks et al. 2001), and (iii) the onset of the European era due to the 'discovery' of New Zealand by James Cook in 1769 with the successive land use changes linked to European settlement and the onset of gold mining at about the same time as the industrial revolution.

Abrahim and Parker (2008) evaluated the heavy metal pollution in the Tamaki Estuary (New Zealand) and found elevated levels of $\mathrm{Cu}, \mathrm{Pb}, \mathrm{Zn}$ and $\mathrm{Cd}$ in the uppermost $10 \mathrm{~cm}$ compared to 'pristine' values in the older sediments. They linked this contamination to the development of the urbanisation and industrialisation in the catchment area especially over the past 50 years. Another study in the Wellington Harbour by Dickinson et al. (1996) showed post-1900 anthropogenic increases in the elements $\mathrm{Cu}, \mathrm{Pb}$ and $\mathrm{Zn}$. However, neither of these studies covers the pre-human era, and thus, it is not clear if the baseline presented shows the actual pristine (pre-human) values or if the presented values already reflect an impact triggered by the Maori's widespread slash-and-burn deforestation (pre-European baseline). Secondly, both studies concentrate on highly urbanised areas with multiple sources for heavy metal input (e.g. industrial areas, port development, dredging, boat yards and yacht anchorages). Thus, the degree of pollution in New Zealand's coastal areas and 'pristine' heavy metal background contents are still only poorly known.

The objectives of this study are to (i) reconstruct past heavy metal inputs, here $\mathrm{Pb}$ and $\mathrm{Zn}$, to the shallow marine environment, (ii) identify the source for humaninduced inputs and (iii) quantify the impact of anthropogenic change by using XRF data obtained on subtidal sediment cores from the Firth of Thames. This is especially important to validate a truly pristine baseline for $\mathrm{Pb}$ and $\mathrm{Zn}$ in order to put past, current and future heavy metal contaminations in relation to the natural background.

\section{Regional setting}

\section{Geography and hydrodynamics}

The Firth of Thames is a mesotidal, shallow estuarine embayment (Naish et al. 1993), located at the north-eastern North Island of New Zealand (Fig. 1). It is part of the north-south striking Hauraki Rift, bounded by the Coromandel-Kaimai Range in the east and Hunua Range in the west (Hochstein and Nixon 1979). The rift continues to the south with the Hauraki Plains. To the north, the Firth is bordered by the Hauraki Gulf. Hydrodynamically, it is a partially to well mixed, tidally dominated estuary with low-wave energy (Naish et al. 1993). On average, tidal currents are $\leq 0.3 \mathrm{~m} \mathrm{~s}^{-1}$ (Black et al. 2000).

Major sediment supply into the Firth of Thames derives from the Waihou River (160 kt/year sediment) and Piako River (30 kt/year sediment) (Hicks et al. 2011), which enter the Firth from the South. With a catchment area of $1984 \mathrm{~km}^{2}$ (Hicks et al. 2011), the Waihou River is the largest river in the Coromandel Region, with several tributaries draining goldmining districts (e.g. Golden Cross, Tui mine) (Webster 1995).

\section{Human impacts on vegetation}

The first major human impact on New Zealand resulted from the widespread forest clearance by the Polynesian settlers. Even though this vegetation change is well recorded in pollen-based paleoenvironmental reconstructions, the exact timing is still under debate and location dependent (McGlone 1983; Newnham et al. 1998; Ogden et al. 1998; McGlone and Wilmshurst 1999; Byrami et al. 2002; Newnham et al. 2018). South of the Coromandel peninsula (Waihi and Kopouatai), the onset of deforestation is dated to $\mathrm{c}$. 1200-1300 CE (Newnham et al. 1995a, b); in the following, $1300 \mathrm{CE}$ is used to refer to this onset. Byrami et al. (2002) give a detailed reconstruction of the vegetation composition from pollen records in the Kauaeranga valley, Coromandel Peninsula: (i) in pre-human times, the native forest was dominated by tall trees (e.g. Podocarpus spp.) and no major changes in floral makeup could be detected over a period of 1000 years, (ii) the onset of deforestation during the Polynesian era is indicated by a significant increase in Pteridium and charcoal as well as a decrease in forest taxa (tall trees), and (iii) the European era is marked by the occurrence of the exotic Pinus spp. pollen and losses in Agathis australis, the New Zealand Kauri tree.

\section{Human impact during European era}

With the establishment of European settlements at c.1845 CE (Augustinus et al. 2006), there was a marked change in land use including further deforestation for agriculture, construction works, Kauri logging and gum digging. Kauri logging posed a special threat for the environment, as it not only meant clearance of native forest, but also damming rivers and regularly flush them in order to transport the logs to the coast in the rough terrain. 


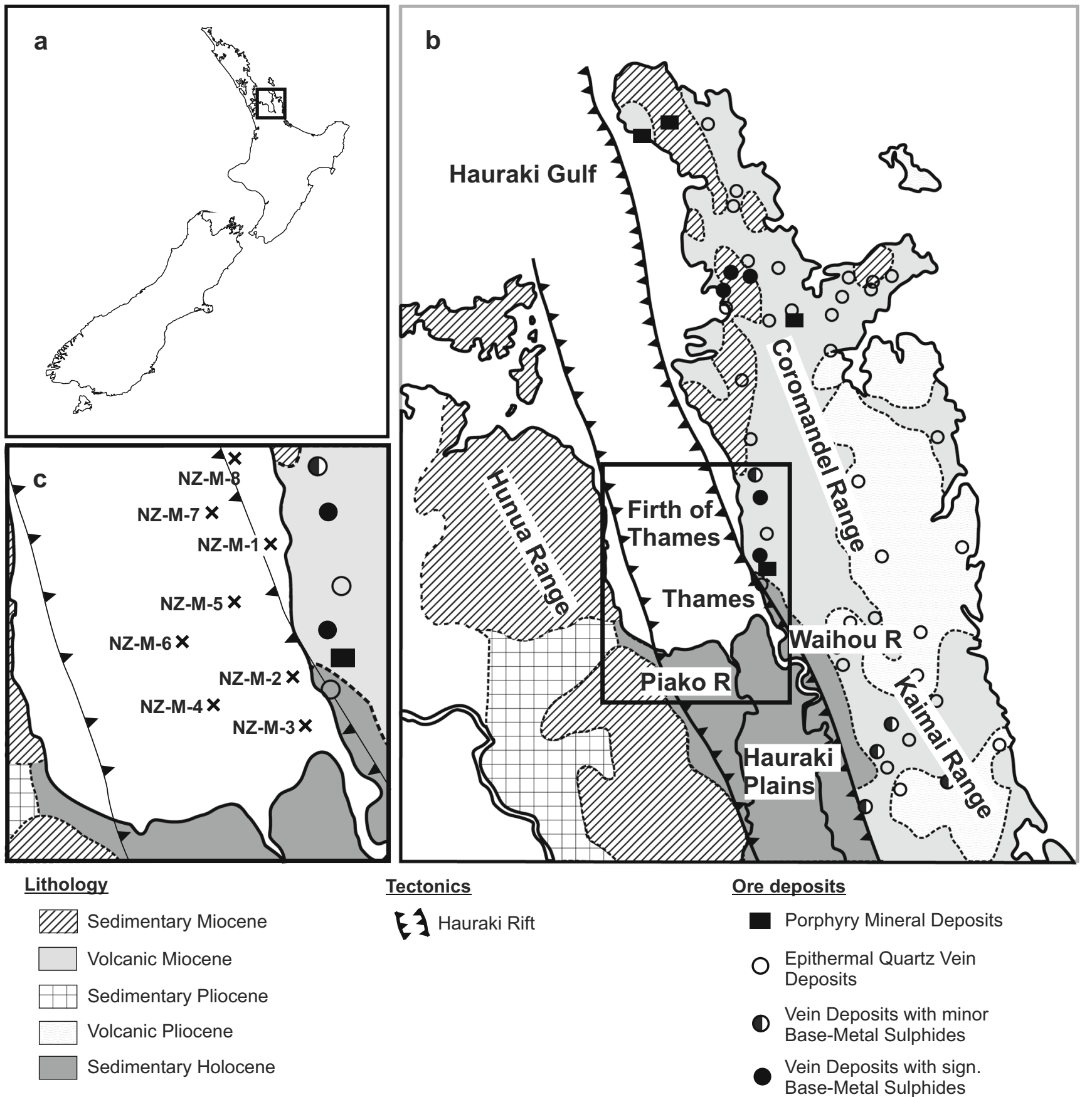

Fig. 1 Overview map of New Zealand (a). Enlarged geological map of the Coromandel region (after Livingston 1987 and Dredge 2014) (b) with ore deposits, many of which have been mining sites in the past

Another major human impact was gold mining operations in the Coromandel Range (Thames started in $1867 \mathrm{CE}$ ). The Coromandel Peninsula consists of Mesozoic greywacke capped and intruded by Neogene andesites and rhyolites (Williams 1974; Adams et al. 1994). Hydrothermal quartz veins cut through these host rocks and scatter small discrete alteration zones with variable gold and base metal content throughout the Coromandel range (Fig. 1) (Williams 1974; Livingston 1987; Brathwaite et al. 2001).
(Livingston 1987). Further enlarged detail map of the Firth of Thames (c) with crosses marking the core locations, circled crosses indicate the three high-resolution principal cores NZ-M-2, NZ-M-4 and NZ-M-7

\section{Materials and methods}

\section{Coring}

The sampling campaign was conducted from March 20 to 22, 2017, on the crane barge Quest belonging to Bay Marine Works Limited. A set of eight sediment cores was collected in the southeastern part of the Firth of Thames (Fig. 1 and Table 1) using a QR 300 Vibracore with 
Table 1 Meta-data of the eight sediment core locations in the Firth of Thames

\begin{tabular}{lllll}
\hline Core no. & Latitude & Longitude & Water depth $(\mathrm{m})$ & Core length $(\mathrm{m})$ \\
\hline NZ-M-1 & $37^{\circ} 02.6894^{\prime} \mathrm{S}$ & $175^{\circ} 30.5168^{\prime} \mathrm{E}$ & 2.6 & 2.47 \\
NZ-M-2 & $37^{\circ} 07.1123^{\prime} \mathrm{S}$ & $175^{\circ} 30.6993^{\prime} \mathrm{E}$ & 1.0 & 2.41 \\
NZ-M-3 & $37^{\circ} 08.9551^{\prime} \mathrm{S}$ & $175^{\circ} 30.8024^{\prime} \mathrm{E}$ & 0.4 & 1.94 \\
NZ-M-4 & $37^{\circ} 08.3227^{\prime} \mathrm{S}$ & $175^{\circ} 26.6615^{\prime} \mathrm{E}$ & 2.2 & 2.50 \\
NZ-M-5 & $37^{\circ} 04.6947^{\prime} \mathrm{S}$ & $175^{\circ} 27.9617^{\prime} \mathrm{E}$ & 5.6 & 2.44 \\
NZ-M-6 & $37^{\circ} 06.2822^{\prime} \mathrm{S}$ & $175^{\circ} 25.7361^{\prime} \mathrm{E}$ & 4.0 & 2.58 \\
NZ-M-7 & $37^{\circ} 01.4124^{\prime} \mathrm{S}$ & $175^{\circ} 27.1250^{\prime} \mathrm{E}$ & 8.5 & 2.46 \\
NZ-M-8 & $36^{\circ} 59.6255^{\prime} \mathrm{S}$ & $175^{\circ} 27.7667^{\prime} \mathrm{E}$ & 7.8 & 2.51 \\
\hline
\end{tabular}

a total weight of $\sim 250 \mathrm{~kg}$ and a tube diameter of $76 \mathrm{~mm}$. The QR 300 Vibracore was configured to take up to 3-mlong cores of unconsolidated or semi-consolidated sediment in a wide range of geological settings. Due to its weight and the very soft sediments in the Firth of Thames, the QR 300 Vibracore was deployed in a gravity corer mode in order to recover undisturbed sediments from the very top layers.

After cutting the 194-258-cm-long sediment cores into 1m-long core segments, these were split along the $c$-axis into working and archive halves. After opening, all cores were described sedimentologically and logged immediately with a handheld X-ray fluorescence (XRF) device (see below). Further analyses focused on three cores ('principal cores': NZ-M-2, NZ-M-4, and NZ-M-7) from which samples from the working and archive halves were taken at discrete depths for radiocarbon dating, wavelength-dispersive XRF (WD-XRF), particle size and pollen analysis (195 samples in total). Archive halves of the principal cores also have been rescanned (prior sampling) with a XRF core scanner.

\section{Age determination}

\section{Radiocarbon dating}

Accelerator mass spectrometry (AMS) radiocarbon $\left({ }^{14} \mathrm{C}\right)$ dating was performed on bulk sediment organic matter $(n=18)$, unclassified marine shells $(n=3)$ and mixed benthic foraminifera $(n=12)$ at the Atmosphere and Ocean Research Institute, University of Tokyo, and at the MICADAS Laboratory, Alfred-Wegener-Institute in Bremerhaven (Table 2). Single-stage accelerator mass spectrometry was used to obtain radiocarbon ages on bulk organic matter (Hirabayashi et al. 2017), with graphitisation completed using the protocol described by Yokoyama et al. (2007, 2010). Sediment samples were pre-treated in $1 \mathrm{M} \mathrm{HCl}$ for $1 \mathrm{~h}$ to remove the calcium carbonate and subsequently heated in a muffle furnace to $850{ }^{\circ} \mathrm{C}$ for $2 \mathrm{~h}$. Carbon incorporated in the sample was recovered as $\mathrm{CO}_{2}$ (Ishizawa et al. 2017). Pre- treatment of marine shell samples followed the protocol of Yokoyama et al. (2007).

Radiocarbon ages were converted to calibrated calendar ages using CALIB 7.1 (Stuiver et al. 2018) based on the Marine13 dataset (Reimer et al. 2013) and no local reservoir correction $(\Delta R=0)$.

\section{Palynological analysis for dating}

Nineteen samples from core NZ-M-4 were prepared for palynological analysis using the standard laboratory procedures (Faegri and Iversen 1989). Sediment $\left(2 \mathrm{~cm}^{3}\right)$ was weighed and dried overnight in a stove at $62{ }^{\circ} \mathrm{C}$. The dried sediment was weighed again, decalcified with diluted $\mathrm{HCl}(10 \%)$ and treated with $\mathrm{HF}(40 \%)$ to remove silicates. One tablet of exotic Lycopodium spores $(18,583 \pm 1708$ spores per tablet) was added to the samples previously to decalcification to allow the calculation of pollen grain abundance. After chemical treatment, samples were wet sieved over a $10-\mu \mathrm{m}$ nylon mesh using an ultrasonic bath to disaggregate organic matter. One aliquot $(50 \mu \mathrm{L})$ was mounted on a permanent glass slide using glycerine jelly, and the slide sealed with paraffin wax. Samples were checked for Pinus spp., Olea europaea and Podocarpus spp. pollen only.

\section{Grain-size analysis}

Grain-size measurements on 115 samples taken from the three principal cores were performed in the Particle-Size Laboratory at MARUM, University of Bremen, with a Beckman Coulter Laser Diffraction Particle Size Analyzer LS 13320. Prior to the measurements, the terrigenous sediment fractions were isolated by removing organic carbon, calcium carbonate and biogenic opal by boiling the samples (in about $200 \mathrm{ml}$ water) with $10 \mathrm{ml}$ of $\mathrm{H}_{2} \mathrm{O}_{2}$ (35\%; until the reaction stopped), $10 \mathrm{ml}$ of $\mathrm{HCl}(10 \% ; 1 \mathrm{~min})$ and $6 \mathrm{~g} \mathrm{NaOH}$ pellets (10 min), respectively. After every preparation step the samples were diluted (dilution factor: $>25$ ). Finally, remaining aggregates were 
Table 2 Radiocarbon dates for the three principal cores NZ-M-2, NZM-4 and NZ-M-7 from the Firth of Thames, New Zealand (bulk OMbulk organic matter; benth. forams - mixed benthic foraminifera; shellunclassified marine shell). The $1 \sigma$ calendar age range given here encloses
$68.3 \%$ of the probability distribution [Stuiver et al. 1998]. Values in parentheses are the relative areas under the probability distribution.*Too young for calibration, therefore CE $1950 \pm 60$ was assumed

\begin{tabular}{|c|c|c|c|c|c|c|}
\hline Laboratory code & Core & $\begin{array}{l}\text { Sample depth } \\
(\mathrm{cm})\end{array}$ & $\begin{array}{l}\text { Sample } \\
\text { material }\end{array}$ & $\begin{array}{l}{ }^{14} \mathrm{C} \text { age } \\
\text { (years BP) }\end{array}$ & $\begin{array}{l}\text { Calendar } \\
\text { age } \mathrm{CE}\end{array}$ & $1 \sigma$ Calendar age range $\mathrm{CE} / \mathrm{BCE}$ \\
\hline YAUT-034228 & NZ-M-2 & 20 & Bulk OM & $2100 \pm 28$ & 273 & cal CE 232-331 (1.000) \\
\hline AWI-1529.1.1 & NZ-M-2 & 26 & Benth. forams & $563 \pm 112$ & 1756 & cal CE $1659-1890(0.987), 1946-1950^{*}(0.013)$ \\
\hline AWI-1529.1.2 & NZ-M-2 & 26 & Benth. forams & $557 \pm 103$ & 1764 & cal CE $1667-1885$ (0.996); 1949-1950* (0.004) \\
\hline YAUT-034229 & NZ-M-2 & 40 & Bulk OM & $962 \pm 30$ & 1393 & cal CE 1353-1374 (0.248); 1381-1430 (0.752) \\
\hline AWI-1729.1.1 & NZ-M-2 & 41 & Benth. forams & Modern & $1950^{*}$ & CE $1890-2010 *$ \\
\hline AWI-1730.1.1 & NZ-M-2 & 56 & Benth. forams & $459 \pm 104$ & 1828 & cal CE $1760-1787(0.123) ; 1803-1950 *(0.877)$ \\
\hline YAUT-034231 & NZ-M-2 & 60 & Bulk OM & $1041 \pm 27$ & 1334 & cal CE 1300-1356 (0.889); 1372-1383 (0.111) \\
\hline YAUT-034702 & NZ-M-2 & 90 & Bulk OM & $5020 \pm 30$ & -3423 & cal BCE 3467-3369 (1.000) \\
\hline AWI-1530.1.1 & NZ-M-2 & 91 & Benth. forams & $1110 \pm 105$ & 1274 & cal CE 1194-1386 (1.000) \\
\hline AWI-1530.1.2 & NZ-M-2 & 91 & Benth. forams & $967 \pm 105$ & 1385 & cal CE $1307-1458(1.000)$ \\
\hline YAUT-034232 & NZ-M-2 & 120 & Bulk OM & $1366 \pm 27$ & 1035 & cal CE 1002-1063 (1.000) \\
\hline YAUT-034723 & NZ-M-2 & 120 & Shell & $935 \pm 37$ & 1414 & cal CE 1387-1454 (1.000) \\
\hline YAUT-032409 & NZ-M-2 & 139.5 & Bulk OM & $2536 \pm 29$ & -265 & cal BCE 322-214 (1.000) \\
\hline YAUT-032403 & NZ-M-2 & 139.5 & Shell & $28,854 \pm 95$ & $-30,465$ & cal BCE 30,755-30,222 (1.000) \\
\hline AWI-1531.1.1 & NZ-M-2 & 141 & Benth. forams & $1893 \pm 103$ & 501 & cal CE 405-623 (1.000) \\
\hline AWI-1531.1.2 & NZ-M-2 & 141 & Benth. forams & $1850 \pm 112$ & 541 & cal CE 436-660 (1.000) \\
\hline YAUT-034703 & NZ-M-4 & 20 & Bulk OM & $930 \pm 28$ & 1420 & cal CE 1401-1450 (1.000) \\
\hline YAUT-034724 & NZ-M-4 & 20 & Shell & $193 \pm 38$ & $1950^{*}$ & CE $1890-2010 *$ \\
\hline AWI-1731.1.1 & NZ-M-4 & 31 & Benth. forams & $550 \pm 48$ & 1771 & cal CE 1692-1822 (1.000) \\
\hline YAUT-034704 & NZ-M-4 & 40 & Bulk OM & $1143 \pm 31$ & 1259 & cal CE 1234-1291 (1.000) \\
\hline AWI-1732.1.1 & NZ-M-4 & 56 & Benth. forams & $848 \pm 48$ & 1474 & cal CE $1438-1508(1.000)$ \\
\hline YAUT-034705 & NZ-M-4 & 60 & Bulk OM & $1041 \pm 31$ & 1336 & cal CE 1300-1358 (0.867); 1371-1384 (0.133) \\
\hline YAUT-034706 & NZ-M-4 & 90 & Bulk OM & $2351 \pm 31$ & -21 & cal BCE 69-cal CE 31 (1.000) \\
\hline YAUT-034709 & NZ-M-4 & 120 & Bulk OM & $1733 \pm 35$ & 664 & cal CE 632-697 (1.000) \\
\hline YAUT-031531 & NZ-M-4 & 148.5 & Bulk OM & $2085 \pm 53$ & 289 & cal CE 224-368 (1.000) \\
\hline YAUT-034713 & NZ-M-7 & 15 & Bulk OM & $1574 \pm 29$ & 813 & cal CE 773-866 (1.000) \\
\hline AWI-1733.1.1 & NZ-M-7 & 16 & Benth. forams & $426 \pm 48$ & $1950 *$ & CE $1890-2010^{*}$ \\
\hline AWI-1734.1.1 & NZ-M-7 & 26 & Benth. forams & $629 \pm 48$ & 1674 & $\begin{array}{l}\text { cal CE } 1591-1609(0.063) ; 1611-1722 \\
\quad(0.926) ; 1793-1797(0.011)\end{array}$ \\
\hline YAUT-034715 & NZ-M-7 & 30 & Bulk OM & $1023 \pm 36$ & 1352 & cal CE 1316-1389 (1.000) \\
\hline YAUT-034716 & NZ-M-7 & 55 & Bulk OM & $1521 \pm 41$ & 873 & cal CE 806-926 (1.000) \\
\hline YAUT-034717 & NZ-M-7 & 80 & Bulk OM & $1508 \pm 36$ & 889 & cal CE 833-948 (1.000) \\
\hline YAUT-034718 & NZ-M-7 & 110 & Bulk OM & $1607 \pm 32$ & 773 & cal CE 722-813 (1.000) \\
\hline YAUT-031536 & NZ-M-7 & 141.5 & Bulk OM & $2674 \pm 65$ & -433 & cal BCE 521-345 (1.000) \\
\hline
\end{tabular}

disaggregated prior to the measurements by boiling the samples with $\sim 0.3 \mathrm{~g}$ tetra-sodium diphosphate decahydrate $\left(\mathrm{Na}_{4} \mathrm{P}_{2} \mathrm{O}_{7} * 10 \mathrm{H}_{2} \mathrm{O}, 3 \mathrm{~min}\right.$ ) (see also McGregor et al. 2009). Sample preparation and measurements were carried out with deionised, degassed and filtered water (filter mesh size: 0.2 $\mu \mathrm{m})$ to reduce the potential influence of gas bubbles or particles within the water. The obtained results provide the particle-size distribution of a sample from 0.04 to $2000 \mu \mathrm{m}$ divided in 116 size classes. The calculation of the particle sizes relies on the Fraunhofer diffraction theory and the Polarization
Intensity Differential Scattering (PIDS) for particles from 0.4 to $2000 \mu \mathrm{m}$ and from 0.04 to $0.4 \mu \mathrm{m}$, respectively. The reproducibility was checked regularly by replicate analyses of three internal glass-bead standards and is found to be better than $\pm 0.7 \mu \mathrm{m}$ for the mean and $\pm 0.6 \mu \mathrm{m}$ for the median particle size $(1 \sigma)$. The average standard deviation integrated overall size classes is better than \pm 4 Vol- $\%$ (note that the standard deviation of the individual size classes is not distributed uniformly). All provided statistic values are based on a geometric statistic. 


\section{Heavy metal analysis}

Portable XRF analyzer (pXRF; energy-dispersive)

A handheld XRF analyzer gun (Olympus Innov-X $50 \mathrm{KV}$ DP4050CX) was used in 'Soil mode' and mounted directly on the smoothed core surface of all collected sediment cores. Sample spots were covered with a thin polypropylene film LS-240-2510 (from Premier Lab Supply Ltd). Contents of major and trace elements were recorded by Innov-X Delta Advanced PC software. Limits of detection for elements analysed by $\mathrm{pXRF}$ are in the ppm range. From a range of elements analysed, only $\mathrm{Pb}$ and $\mathrm{Zn}$ are used. Each scan took $90 \mathrm{~s}$ with calibration checks made every 30 samples on a reference material (Stainless Steel Calibration Check Reference Coin provided by Olympus) for evaluation of accuracy. Expecting anthropogenic impact only in the youngest sediments, sample spacing was $5 \mathrm{~cm}$ for the upper $21 \mathrm{~cm}$ of the cores and $10 \mathrm{~cm}$ further downcore.

\section{XRF core scanner (energy-dispersive)}

XRF Core Scanner data were collected with the XRF Core Scanner III (AVAATECH Serial No. 12) at the MARUM University of Bremen on the three principal cores every $1 \mathrm{~cm}$ downcore over a $1.2 \mathrm{~cm}^{2}$ area with downcore slit size of $10 \mathrm{~mm}$ using generator settings of 10,30 and $50 \mathrm{kV}$, a current of $0.05 \mathrm{~mA}(10 \mathrm{kV})$ and $0.5 \mathrm{~mA}(30$ and $50 \mathrm{kV})$ respectively. The sampling time was $10 \mathrm{~s}$ directly at the split core surface of the archive half, which was covered with a 4- $\mu$ m-thick SPEXCerti Prep Ultralene1 foil to avoid contamination of the XRF measurement unit and desiccation of the sediment. The data were acquired by a SGX Sensortech Silicon Drift Detector (Model SiriusSD®) D65133Be-INF with $133 \mathrm{eV}$ X-ray resolution), the Topaz-X High-Resolution Digital MCA and an Oxford Instruments $100 \mathrm{~W}$ Neptune $\mathrm{X}$-Ray tube with rhodium $(\mathrm{Rh})$ target material. Raw data spectra were processed by the analysis of X-ray spectra by the Iterative Least square software (WIN AXIL) package from Canberra Eurisys and interpreted for $\mathrm{Pb}$ and $\mathrm{Zn}$.

\section{XRF spectrometer (wavelength-dispersive)}

For quantification, 28 discrete samples of $20 \mathrm{~g}$ wet sediment were taken from the three principal cores at positions that cover the full range of $\mathrm{Zn}$ and $\mathrm{Pb}$ values according to the semi-quantitative XRF core scanner measurements. Samples were kept in the drying cabinet at $40^{\circ} \mathrm{C}$ for $48 \mathrm{~h}$ and ground using a ring mill. Prior to the analysis, $700 \pm 0.6 \mathrm{mg}$ per sample were weighted into a ceramic crucible and mixed with $4200 \pm 1 \mathrm{mg}$ of a di-lithium tetraborate fusion flux (SpectromeltR A10, Merck) and about $1000 \mathrm{mg}$ of ammonium nitrate. Following the pre-annealing at $500{ }^{\circ} \mathrm{C}$ overnight, the samples were fused into glass beads and analysed via wavelength dispersive XRF-spectrometry (WD-XRF) at the ICBM, Institut für Chemie und Biologie des Meeres, at the University of Oldenburg. For the determination of precision and accuracy of the method, the in-house standard PS-S was used (root means square error for $\mathrm{Zn}(\mathrm{Pb}) 9 \mathrm{ppm}$ (5 ppm); precision in rel-\% for $\mathrm{Zn}(\mathrm{Pb})=1(7))$.

\section{Calibration of X-ray fluorescence data}

The net intensities for $\mathrm{Pb}$ and $\mathrm{Zn}$ in counts per second (cps) measured with the XRF Core Scanner were divided by the total cps from the according $30 \mathrm{kV}$ run to normalise the data (i.e. for deviations resulting from varying water content, grainsize variations and others). These normalised net intensities from the XRF Core Scanner data were converted to element contents using linear regressions between XRF scannerderived intensities and element contents measured on the corresponding 28 discrete samples measured quantitatively (e.g. Jansen et al. 1998; Kido et al. 2006; Tjallingii et al. 2007). The obtained data of the pXRF were calibrated using the same equation, but normalisation was not conducted as values given by the instrument were already in ppm.

\section{Results}

\section{Core description}

A strong $\mathrm{H}_{2} \mathrm{~S}$ smell was obvious after splitting of the cores NZ-M-1, NZ-M-4, NZ-M-5, NZ-M-6, NZ-M-7 and NZ-M-8. These cores consist of a dark greenish mud (Munsell $5 \mathrm{Y}$ colour chart) with only minor internal textures, which include thin layers of fine sand or shell debris. No lamination, burrowing or change in colour was observed. In general, the cores revealed no obvious changes in grain size with the exception of cores NZ-M-2 and NZ-M-3. Core NZ-M-2 is composed of fine-sandy material in the core section below $96 \mathrm{~cm}$ that gradually changed to the same dark greenish, homogeneous mud as described before with a minor sand content $(<5 \%)$ that makes up the uppermost $90 \mathrm{~cm}$ of the core. Core NZ-M-3 (near Waihou river mouth) is dominated by black middle to coarse sand with fine shell debris and had a smell of rotten fish. In the sediments below $120 \mathrm{~cm}$ depth, the sand alternates with black muddy layers similar to those described from the other cores, but very compact.

\section{Radiocarbon dating}

For all three principal cores (NZ-M-2, NZ-M-4, and NZ-M-7), the 33 obtained ${ }^{14} \mathrm{C}$ dates show generally a consistent trend to become younger towards the top with the exception of only a few samples (Table 2). Such 'outliers' are restricted to either 
bulk organic matter or not classified shell dates. The upper $150 \mathrm{~cm}$ of cores NZ-M-2 and NZ-M- 4 comprise $\sim 1500$ years and $\sim 1660$ years, respectively. Core NZ-M-7 shows slightly older ages and shows an age of 2380 years in $141 \mathrm{~cm}$ sediment depth. Therefore, the pre-human era is covered in all three cores. NZ-M-2 is the core with the most radiocarbon dates on foraminifera $(n=8)$ with the four ages above $56 \mathrm{~cm}$ showing ages of $<\sim 250$ years. Taking the $1 \sigma$ range into account, the resulting ages overlap without any age reversals and all dates potentially reach the time past $1840 \mathrm{CE}$. Below $56 \mathrm{~cm}$, the samples become successively older and date back to $\sim 405$ $\mathrm{CE}$ (maximum $1 \sigma$ age) in $141 \mathrm{~cm}$ depth. The cores NZ-M-4 and NZ-M-7 contain only two radiocarbon dates on foraminifera with no age reversals. In both cases, the deeper sample represents the Polynesian era (NZ-M-4 at $56 \mathrm{~cm}=1438-1508$ $\mathrm{CE}$; NZ-M-7 at $26 \mathrm{~cm}=1611-1722 \mathrm{CE}$ ), whereas the upper sample falls into the European era (NZ-M-4 at $31 \mathrm{~cm}=1692$ 1822 CE; NZ-M-7 at $16 \mathrm{~cm}=$ modern CE). The ${ }^{14} \mathrm{C}$ data from mixed benthic foraminifera are generally younger than those obtained on bulk organic matter. Radiocarbon ages too young for a calibration with CALIB 7.1 were assumed to be $1950 \pm$ $60 \mathrm{CE}$ and are marked in Table 2 with an asterisk.

\section{Palynology}

Core NZ-M-4 has been analysed for the occurrence of pollen from Podocarpus spp., Pinus spp. and Olea europaea with 19 samples taken from $17 \mathrm{~cm}$ down to $230 \mathrm{~cm}$ core depth (Fig. 2). For the amount of Podocarpus spp. pollen, a general decrease in the number of pollen per gram from the core base towards the core top is obvious, with a slower decline from 230 to

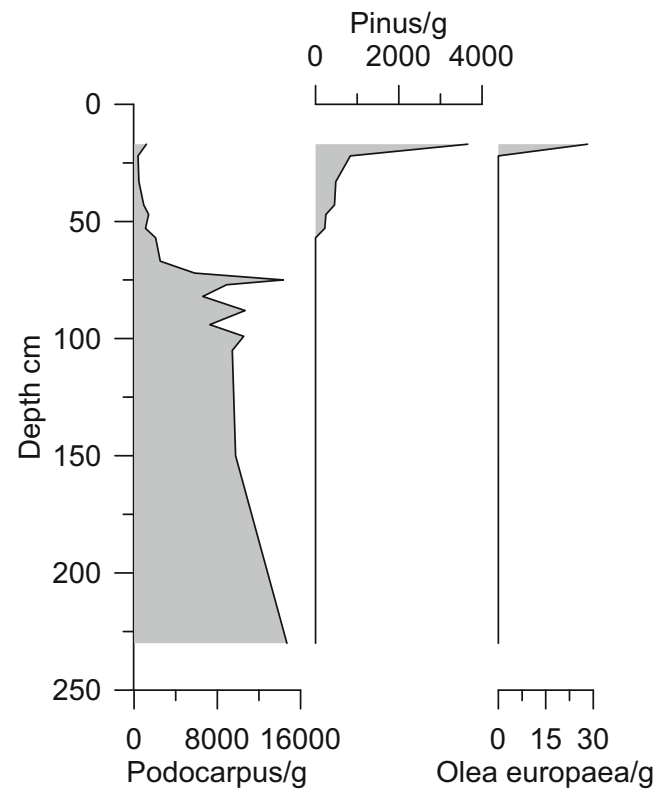

Fig. 2 Pollen data of core NZ-M-4 showing the absoluteabundances (number per grams) of the counted pollen types (Podocarpus, Pinus, Olea europaea)
$72 \mathrm{~cm}$ and a sharp drop above $72 \mathrm{~cm}$. The first specimen of Pinus spp. pollen occurs in a depth of $53 \mathrm{~cm}$ with a constant increase to a depth of $22 \mathrm{~cm}$. In the very top sample at $17 \mathrm{~cm}$ depth, an extensive increase in Pinus spp. is recorded. Additionally, this is the only sample were a specimen of Olea europaea was found, another exotic plant to New Zealand with the earliest records of naturalisation in the 1970s (Heenan et al. 1999).

\section{Grain-size analysis}

Core NZ-M-2 displays the already macroscopic observed change in grain size. From 226 to $91 \mathrm{~cm}$, the sediment is rather coarse in the fine sand range (mean $\sim 70 \mu \mathrm{m}$, mode $\sim 195$ $\mu \mathrm{m})$, whereas from $91 \mathrm{~cm}$ to the core top, the grain size is significantly finer (mean $\sim 13 \mu \mathrm{m}$, mode $\sim 19 \mu \mathrm{m}$ ) (Fig. 3). The cores NZ-M-4 and NZ-M-7 consist dominantly of silt and clay and show no major changes in grain size. In comparison, core NZ-M-4 (mean $\sim 14 \mu \mathrm{m}$, mode $\sim 30 \mu \mathrm{m}$ ) is slightly coarser than core NZ-M-7 (mean $\sim 9 \mu \mathrm{m}$, mode $\sim 15 \mu \mathrm{m}$ ) that has been retrieved somewhat further offshore.

\section{Calibration of pXRF and XRF scanner data}

To quantify the semi-quantitative pXRF and XRF Scanner data, they have been calibrated with the WD-XRF data. The correlation plots with the 28 discrete samples analysed with WD-XRF show that the scanner data provide better correlation factors than the pXRF data (Fig. 4). For the XRF Scanner data, $\mathrm{Pb}\left(R^{2}=0.97\right)$ has a higher correlation than $\mathrm{Zn}\left(R^{2}=\right.$ 0.87 ), but both show a good fit. For pXRF, the correlations with the discrete samples are less significant, but still show a clear positive correlation for $\mathrm{Pb}\left(R^{2}=0.81\right)$ and $\mathrm{Zn}\left(R^{2}=0.72\right)$. The correlation between the XRF Scanner and the pXRF was used as additional verification for data reliability. Correlation factors for the two elements are good and show no difference between $\mathrm{Pb}\left(R^{2}=0.89\right)$ and $\mathrm{Zn}\left(R^{2}=0.89\right)$. Using the corresponding correlation equations gives higher quantitative $\mathrm{Pb}$ and $\mathrm{Zn}$ contents for calibrated XRF Scanner data than for pXRF data. This offset can be explained by the lower beam energy of the pXRF compared to the XRF Scanner, affecting the detection limits. Therefore, lower contents of $\mathrm{Pb}$ and $\mathrm{Zn}$ are only resolved in the XRF Scanner data, giving a different linear regression equation for the two applied methods. The lower beam energy results additionally in lower analytical precision of the pXRF (Young et al. 2016).

\section{Calibrated pXRF data}

Calibrated pXRF data show a distinct and sudden peak in $\mathrm{Pb}$ and $\mathrm{Zn}$ in the upper part of six of the eight cores with varying contents and depths of onset (Fig. 5). Values below the peaks are very constant within the cores as well as between the cores with 


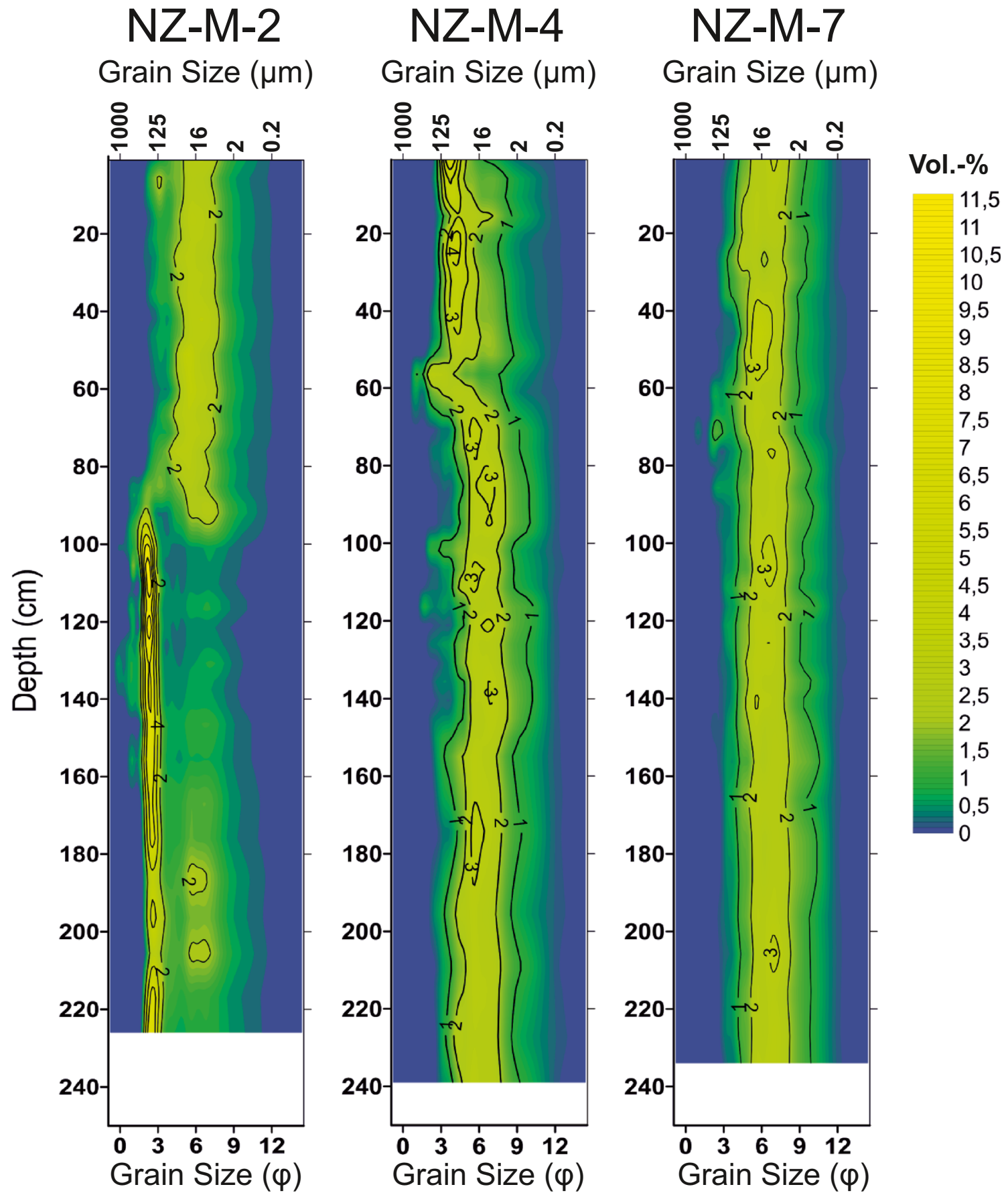

Fig. 3 Grain-size distribution of the three principal cores NZ-M-2 (near river, coastal), NZ-M-4 (near river, offshore) and NZ-M-7 (far from river), colour coding gives percentage of each grain-size class, varying from $11.5 \%$ (yellow) to $0 \%$ (blue) values around $12 \mathrm{ppm}$ for $\mathrm{Pb}$ and $50 \mathrm{ppm}$ for $\mathrm{Zn}$. Exceptions are cores NZ-M-2 and NZ-M-3 with slightly higher values of $18 \mathrm{ppm}$ for $\mathrm{Pb}$ and $80 \mathrm{ppm}$ for $\mathrm{Zn}$ in the lower core sections.

Cores NZ-M-2 and NZ-M-4 display very distinct peaks in their uppermost $56 \mathrm{~cm}$ and $54 \mathrm{~cm}$, which also show the highest $\mathrm{Pb}$ and $\mathrm{Zn}$ contents of all cores $(\mathrm{Pb}$ up to $90 \mathrm{ppm}$ in NZ-M-2 and $120 \mathrm{ppm}$ in NZ-M-4; Zn up to $190 \mathrm{ppm}$ and $300 \mathrm{ppm}$ respectively). The cores NZ-M-7 and NZ-M-8 located furthest north have less pronounced peaks with lower contents and onsets of the peaks higher up in sediment column. Nevertheless, all these four cores show the same pattern in peak structure with a pronounced increase and a following decrease in $\mathrm{Pb}$ and $\mathrm{Zn}$ content towards the core top. The $\mathrm{Pb}$ and $\mathrm{Zn}$ contents of cores NZ-M-1, NZ-M-3 and NZ-M-5 increase only very close to the core tops $(11-16 \mathrm{~cm})$, and no increase at all was detected in core NZ-M-6. 


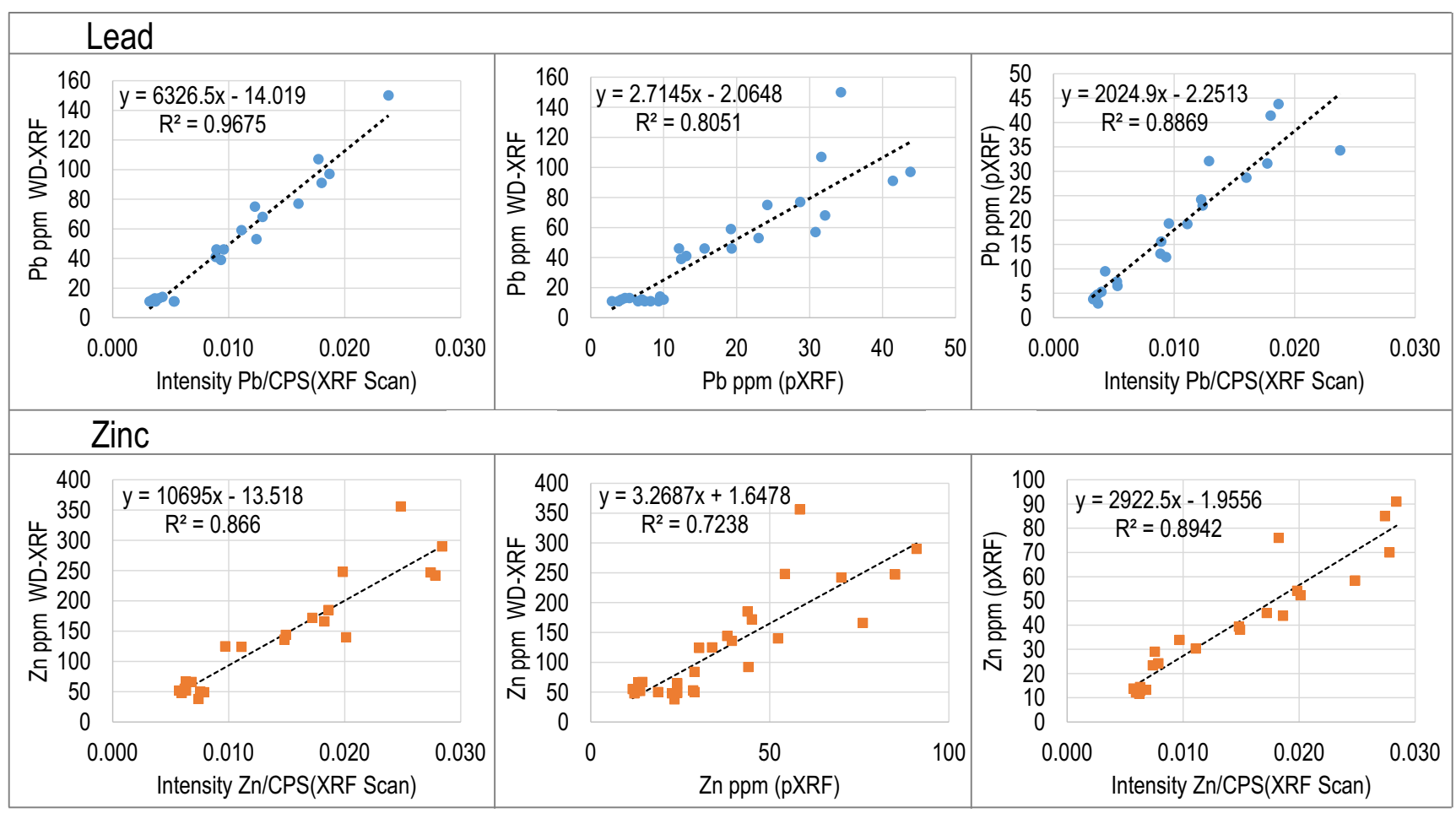

Fig. 4 Correlation diagrams of the different XRF methods (XRF Scan, pXRF, WD-XRF) and empirically established linear equations for

calibrating the XRF Scanner and the pXRF data with the quantitative WD-XRF results
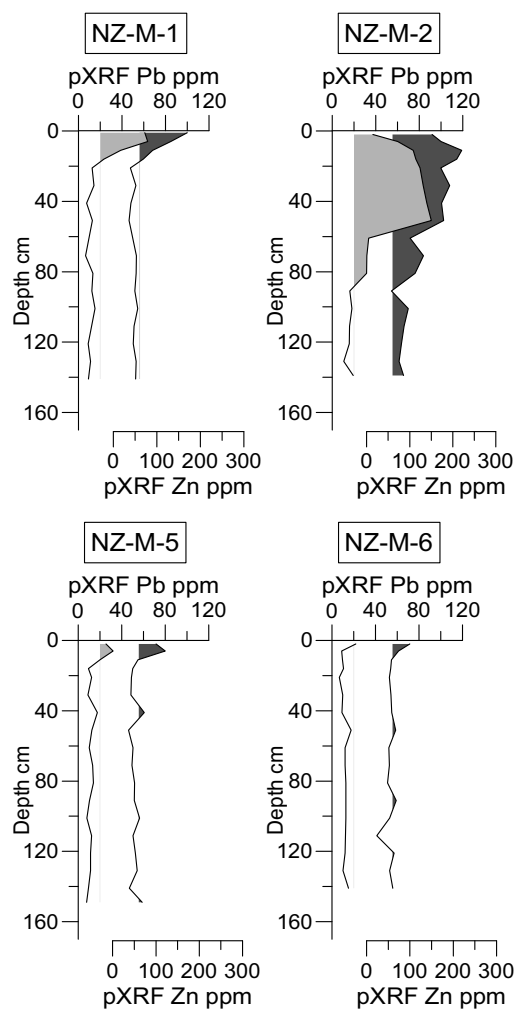

Fig. 5 Regional and vertical distribution pattern of $\mathrm{Pb}$ and $\mathrm{Zn}$ contents in the Firth of Thames sediments obtained by calibrated portable XRF data. Light grey shading marks $\mathrm{Pb}$ contents $>20 \mathrm{ppm}$, dark grey shadings
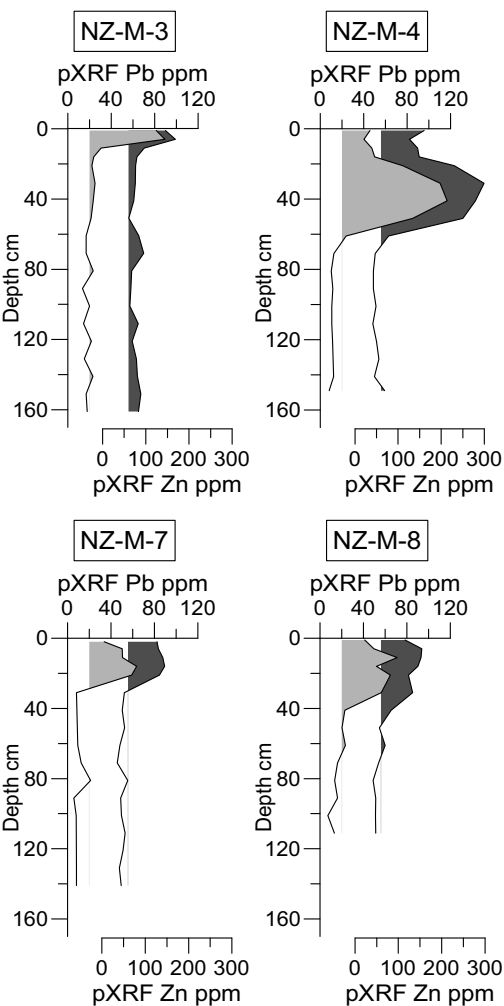

represent $\mathrm{Zn}$ contents $>60 \mathrm{ppm}$. Circles represent core locations, red circles - three high-resolution principal cores, black circles - other cores 


\section{Calibrated XRF scan data (principal cores)}

The temporal and spatial patterns of the pXRF data were confirmed by the calibrated XRF Scan results of the three cores NZ-M-2, NZ-M-4 and NZ-M-7 (Fig. 6), which, however, provide a much higher temporal resolution. In the lower part of core NZ-M-4, rather constant values around $12 \mathrm{ppm}$ for $\mathrm{Pb}$ and $57 \mathrm{ppm}$ for $\mathrm{Zn}$ can be observed. At $54 \mathrm{~cm}$ core depth, both values increase steeply to a maximum at $34 \mathrm{~cm}$ depth and show from there a general declining trend towards the top of the core. The heavy metal content at the sediment surface is still clearly above the background values found in the lower part of the core. The average content of this section is $82 \mathrm{ppm}$ for $\mathrm{Pb}$ and $236 \mathrm{ppm}$ for $\mathrm{Zn}$. Core NZ-M-7 shows a very similar pattern, but with generally lower values and the onset of the strong increase higher up in the core at $26 \mathrm{~cm}$.

Core NZ-M-2 is exceptional, as a two-step increase in heavy metals was recorded in both independent XRF data sets. Heavy metal values stay very constant at $14 \mathrm{ppm}(\mathrm{Pb})$ and $65 \mathrm{ppm}(\mathrm{Zn})$ from the core bottom up to $93 \mathrm{~cm}$ depth. Above this boundary, matching with the change in grain size, the level of $\mathrm{Pb}(44 \mathrm{ppm})$ and $\mathrm{Zn}(101 \mathrm{ppm})$ is elevated abruptly. This step is followed by a second, even sharper increase to average contents of $100 \mathrm{ppm}$ for $\mathrm{Pb}$ and $235 \mathrm{ppm}$ for $\mathrm{Zn}$ at $56 \mathrm{~cm}$. Towards the core top also in this core, $\mathrm{Pb}$ and $\mathrm{Zn}$ contents decline again but stay above the lower core section values.

\section{Discussion}

\section{Development of the stratigraphic framework}

Despite the high number of available radiocarbon dates $(n=$ 33), the overall scatter of the data makes the development of a stratigraphic framework for the three principal cores focusing on the delineation of the three eras discussed above rather complex (Fig. 7). Here, the final stratigraphic frameworks are built on three premises: (i) mixed benthic foraminifera as best representing the average sedimentation give the most reliable ages of the different materials dated and are therefore taken as hard constraints, (ii) the first occurrence of exotic pollen is a distinct marker for the beginning of the European era and (iii) radiocarbon dates based on organic matter can serve only to constrain maximum ages (soft constraints). Ages obtained from bulk organic matter are known to be generally older than the time of actual deposition, as they have long residence times, depending on the size, morphology and climate of the catchment area (Blaauw et al. 2011). Shells were only regarded if their dates fitted into the overall pattern, as older shells are most likely re-deposited within this very shallow setting. Thus, in a first step, the age-depth relationship attained from radiocarbon dating on foraminifera by interpolation is accepted as the most reliable (solid line, Fig. 7). Minor age reversals covered by the $1 \sigma$ range could be influenced by bioturbation or some disturbance related to the shallow water depth and are not considered here.

With respect to premise (ii), two additional palynological dates were established for core NZ-M-4 at $53 \mathrm{~cm}$. The

Fig. 6 High-resolution calibrated XRF Scanner data for the three principal cores with the interpreted age zonation of the pre-human, Polynesian and European Era. Averaged $\mathrm{Pb}$ and $\mathrm{Zn}$ contents were calculated from all values above the peak onset and below the peak onset respectively. Solid lines are based on the stratigraphic frameworks. Dotted lines extrapolated under the assumption of similar relative changes in sedimentation rates in all cores

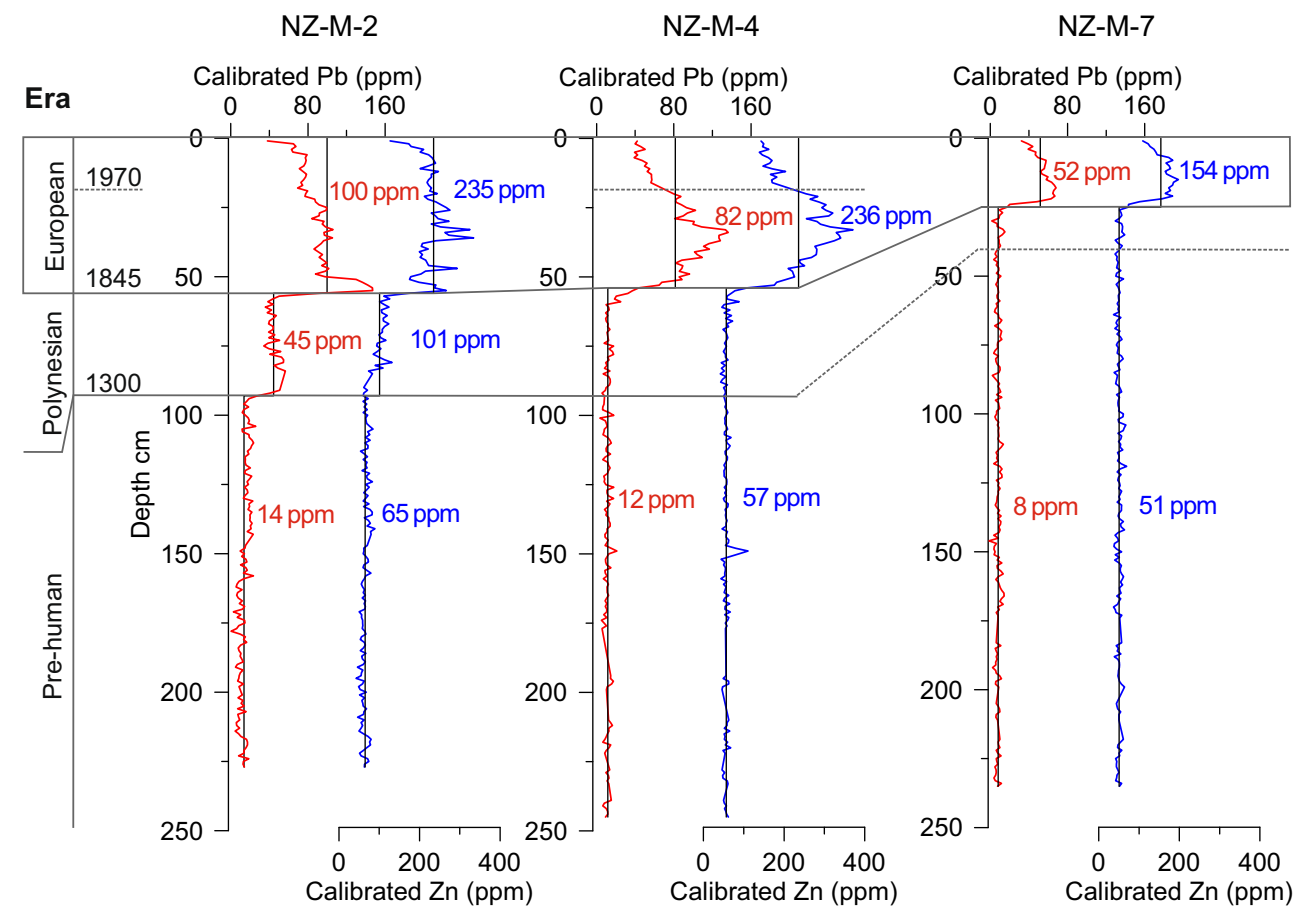




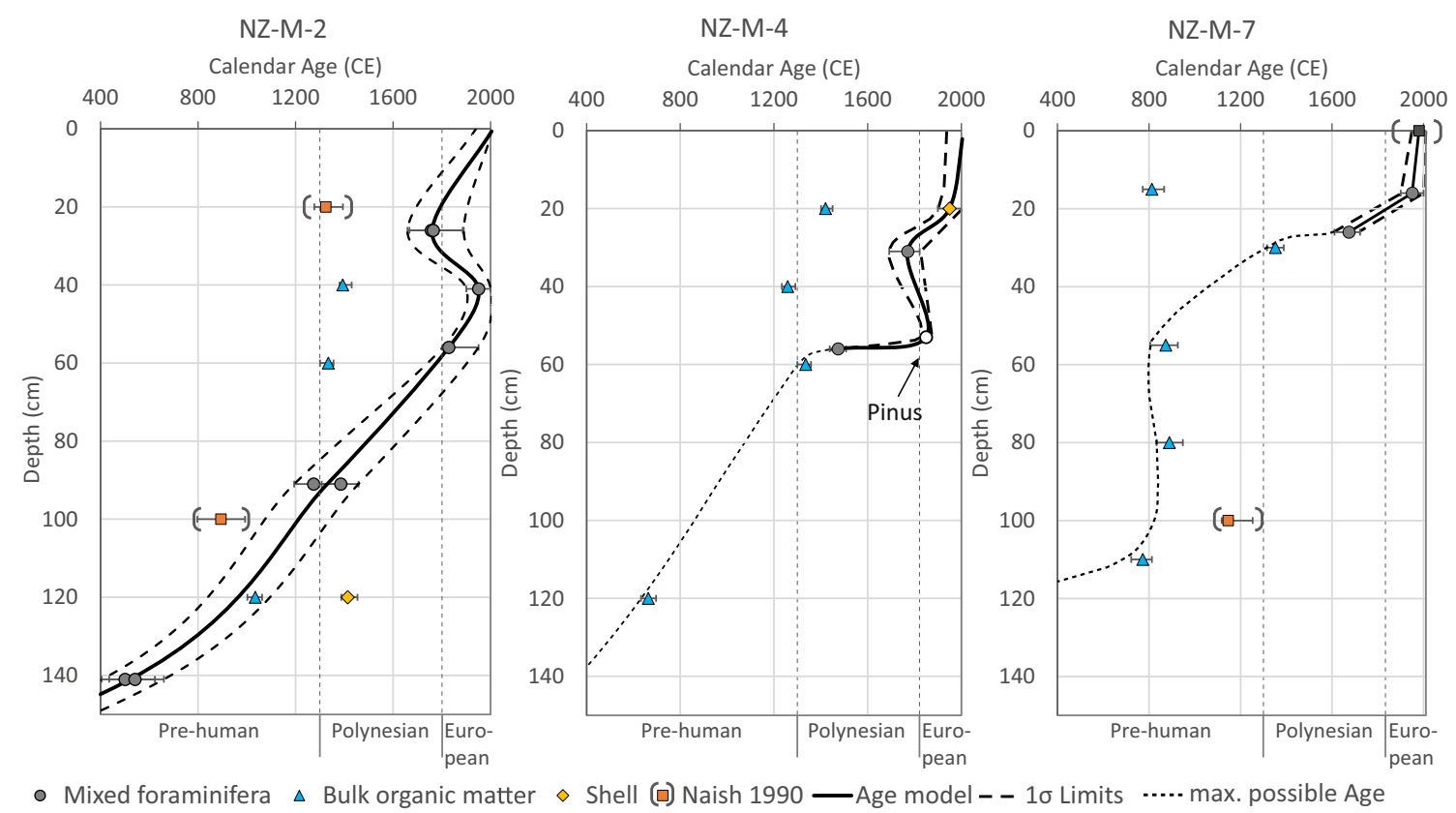

Fig. 7 Stratigraphic frameworks for the three principal cores NZ-M-2, NZ-M-4 and NZ-M-7. Solid black line is the interpolation between the calibrated ages of the values considered as reliable. Dashed black line is the upper and lower limit based on the $1 \sigma$ range of the reliable data.

occurrence of Pinus spp. pollen in New Zealand lake and coastal sediments is widely used as stratigraphic event that marks the onset of the European era in $\sim 1845 \mathrm{CE}$ (Augustinus et al. 2006). Consequently, the first occurrence of Pinus spp. pollen at $53 \mathrm{~cm}$ in core NZ-M-4 was dated to 1845 CE. Furthermore, the drastic increase in the content of Pinus spp. pollen in the sediment at $17 \mathrm{~cm}$ depth is interpreted as the first evidence of pine plantations, which were established in the 1970s (Hume and Dahm 1992). This interpretation is supported by the occurrence of the only Olea europaea pollen found in the core, as the oldest records of this species in New Zealand are from the 1970s (Heenan et al. 1999). This allows for core NZ-M-4 to differentiate the European era into an historic and recent part (Fig. 6). Furthermore, in the same core at $20 \mathrm{~cm}$ depth, a reliable shell-based date reveals a recent age $(\sim 1950 \mathrm{CE}$, Fig. 7$)$.

All stratigraphic frameworks, interpreted here solely to differentiate between the European, the Polynesian, and the prehuman eras, were forced to go through $2010 \mathrm{CE}$ at the sediment surface. This assumption is supported by the foraminifera as well as pollen dates obtained in this study and reinforced by a modern radiocarbon date (CE $1950 \pm 60)$ from Naish (1990) at the sediment surface of a core taken in less than $5-\mathrm{km}$ distance from core NZ-M-7. A comparison of the stratigraphic framework of this study to published age-depth relationships based on shells and wood fragments for two cores taken within less than $5 \mathrm{~km}$ from the cores NZ-M-2 and NZ-M-7, respectively, (orange squares in Fig. 7; Naish 1990) shows a reasonable good agreement of the general sedimentation rates.
Dotted line represents the maximum possible age for the lower sections of NZ-M-4 and NZ-M-7. Orange squares in parentheses are dates obtained on cores in less than $5 \mathrm{~km}$ distance from the NZ-M core sites (Naish 1990)

\section{Sedimentation rates}

A comparison of the resulting sedimentation rates for the principal cores with rates obtained from the same area (Naish 1990; Hume and Dahm 1992) shows that all rates are in the same order of magnitude (Table 3). Even though the sedimentation rates presented here are higher than those previously reported, all three data sets document that sedimentation rates were significantly lower during the pre-human and Polynesian era $(<0.65 \mathrm{~mm} /$ year $)$ and increased with the onset of the European era (up to $3.2 \mathrm{~mm} /$ year). On average, all data indicate an approximately fourfold increase in sedimentation rate upon the beginning of the European era. Additionally, the pollen data in core NZ-M-4 indicate that the sedimentation rates in the recent European era are even higher than in the historic one. Acceleration of sedimentation rates during European times was already suspected by Hume and Dahm (1992) and suggested to be additionally enhanced by the establishment of pine plantations in the 1970s. The lack of reliable ages in the lower sections of the NZ-M cores does preclude any differentiation between the pre-human and Polynesian eras, and therefore, no statement can be made whether the Polynesian deforestation had an impact on sedimentation rates.

\section{Timing of increase in heavy metal inputs}

For the older parts of the cores, especially for the pre-human and the early Polynesian eras, a well-defined stratigraphic 
Table 3 Comparison of sedimentation rates in the southeastern Firth of Thames in millimeter per year. n.a. - not available

\begin{tabular}{lllllll}
\hline & \multicolumn{3}{c}{ This study } & & Naish (1990) & Hume and Dahme (1992) \\
\hline \multirow{4}{*}{ European } & Recent & & 3.8 & & & \\
& Historic & & 2.8 & & & \\
& Overall & 3.2 & 3.1 & 1.5 & $1.9-2.1$ & 0.5 and $1.3-1.5$ \\
Polynesian & & 0.65 & n.a. & n.a. & $0.35-0.45$ & $0.1-0.4$ \\
Pre-human & & n.a. & & & n.a. & $0.1-0.2$ \\
\hline
\end{tabular}

framework only exists for core NZ-M-2. The sedimentation rate of NZ-M-2 for the Polynesian era has been extrapolated to core NZ-M-4, which appears as a valid assumption as both cores also have very similar sedimentation rates for the European era. Extrapolation for NZ-M-7 (dashed line in Fig. 6) is based on the assumption that sedimentation rates in this distal location were constantly half of the sedimentation rates close to the Waihou River, as it is the case for the European era.

The two reliable radiocarbon ages in $91 \mathrm{~cm}$ depth of core NZ-M-2 give an age of $1350 \mathrm{CE}$, which slightly postdates the arrival of the Polynesians. This is close to the depth level of $96 \mathrm{~cm}$ where the sediments get significantly finer and enriched in heavy metals. Interestingly, in the other two principal cores, neither the two-step increase in heavy metal contents (Figs. 5 and 6) nor the shift in grain size (Fig. 3) are recorded. However, assuming a sedimentation rate for the Polynesian era of $\sim 25 \%$ of that corresponding to the European era, all principal cores should cover the change from the pre-human to the Polynesian era (see correlation in Fig. 6 for the principal cores). Consequently, the two-step increase in core NZ-M-2 is interpreted to reflect a local sedimentological change at this near-coastal site (e.g. a meandering tidal channel) that primarily affected the grain-size distribution. The accompanying shift towards higher heavy metal contents probably reflects a simple grain-size effect caused by higher loadings of heavy metals of finer particles due to their larger capacity for adsorption (Förstner and Wittmann 1981). As cores NZ-M-4 and NZ-M-7 show no changes neither in XRF nor in grain size, the precise determination of the boundary between the pre-human and Polynesian era is difficult, but obviously it is not accompanied by any significant anthropogenic impact.

The coherent pattern with continuously low heavy metal contents through the pre-human as well as the Polynesian era in all the cores (except NZ-M-2) indicates that the Polynesians did not leave any sizable impact on the heavy metal budget in the Firth of Thames. Instead, the sudden increase in heavy metal contents in six out of eight investigated cores (Fig. 5) can be correlated with the European era based on the stratigraphic information available for the three principal cores (Fig. 6).
In cores NZ-M-2 and NZ-M-4, both located in the inner Firth of Thames, the increase in heavy metal contents occurs in $56 \mathrm{~cm}$ and $54 \mathrm{~cm}$ core depth, respectively, corresponding to a radiocarbon age of $\sim 1830 \mathrm{CE}$ (NZ-M-2) as well as to the onset of Pinus spp. pollen deposition (NZ-M-4) corresponding to $\sim 1845 \mathrm{CE}$ (Augustinus et al. 2006). In core NZ-M-7 from a more distal position in the central Firth of Thames, $\mathrm{Pb}$ and $\mathrm{Zn}$ contents increase in $26 \mathrm{~cm}$ core depth, radiocarbon dated to $\sim 1670 \mathrm{CE}$. However, linking the increase in heavy metal contents (Fig. 6) with the increase in sedimentation rate (see the slopes of the curves in Fig. 7) clearly reflects the same pattern as in the other two cores. Thus, also the somewhat older age at this site points to the impact of the European settlers causing the enhanced deposition of heavy metals. The comparably old radiocarbon age might be affected by the significantly lower average sedimentation rate at this site that likely allows for a larger bioturbation bias in the dating and/or 'smear' the onset of the $\mathrm{Pb}$ and $\mathrm{Zn}$ signal to some degree into the deeper sediment.

As the grain-size data show no change associated with the increase in heavy metals, any grain-size effect can be excluded pointing to a real input signal. Thus, based on (i) the similar pattern of the $\mathrm{Pb}$ and $\mathrm{Zn}$ contents in the cores (i.e., decreasing contents/thicknesses of the polluted sediments with increasing distance from the source; excl. NZ.M-3, see above) and (ii) the fit between the radiocarbon and the pollen data defining the onset of the increase, it is concluded that the increase in heavy metal input to the Firth of Thames correlates with the onset of the European era.

Furthermore, all three principal cores show a decline in heavy metal content towards the core top (Fig. 6), most pronounced in core NZ-M-4 above maximum $\mathrm{Pb}$ and $\mathrm{Zn}$ contents at $34 \mathrm{~cm}$. In the same core, the rapid increase in the number of Pinus spp. pollen and the occurrence of Olea europaea, at $17 \mathrm{~cm}$ depth, roughly mark the year $\sim 1970$ CE. This indicates that in the second half of the twentieth century the input of heavy metals into the Firth of Thames already decreased, coinciding with a decline in mining activity in the Coromandel region with main operations between 1890s and 1930s (Kidd 1988). 


\section{Cause of elevated heavy metal levels}

The main evidence for the source of pollution is provided by the stratigraphic framework, placing the marked increase in heavy metal contents in the Firth of Thames sediments clearly into the European era. As sedimentary $\mathrm{Pb}$ and $\mathrm{Zn}$ contents were rather low and constant during the pre-human and Polynesian eras, the increase in heavy metal inputs points to a cause unique to activities of the European settlers.

The prime candidate here is mining. During the early gold mining operations (1850s to 1950 s) along the Coromandel Peninsula, substantial volumes of mine waste were dumped directly into the Firth of Thames and discharge of tailings into the Waihou River and its tributaries occurred (e.g. Webster 1995; Craw and Chappell 2000). Typical contaminants in these mine tailings are $\mathrm{Pb}$ and $\mathrm{Zn}$ as well as $\mathrm{Cu}$ and $\mathrm{As}$ (Hume and Dahm 1992; Christie et al. 2007). As in this region the gold is associated with sulphide-rich sections of hydrothermally altered host rock, these elements were probably released to the Firth of Thames through oxidation and leaching of the mine waste (Garrels and Thompson 1960; Livingston 1987; Craw and Chappell 2000). Elevated $\mathrm{Cu}$ and As contents were detected neither in the XRF Scan nor in the pXRF data, but there are indications from the WD-XRF that these elements show similar enrichments as $\mathrm{Pb}$ and $\mathrm{Zn}$ in the Firth of Thames sediments. Most certainly, the $\mathrm{Cu}$ and $\mathrm{As}$ contents are too low to be detected by the energy-dispersive methods (B. Schnetger, pers. communication).

The strongest enrichment in heavy metals was recorded near the Waihou River (cores NZ-M-2 and NZ-M-4), which is, together with its tributaries the Tui Stream and Ohinemuri River, known to be strongly influenced by mining operations (Webster 1995). In addition, elevated $\mathrm{Zn}$ and $\mathrm{Pb}$ levels also have been found near the coast of the Coromandel Peninsula, where small streams drain the mining areas. The sediments from these streams are also characterised by enhanced $\mathrm{Zn}(106-720 \mathrm{ppm})$ and $\mathrm{Pb}(18-85 \mathrm{ppm})$ contents (Sheppard et al. 2009).

The main period of gold mining operations in the Coromandel range ended with the closure of the Martha mine in 1952 (Christie et al. 2007), although most of the mines were already closed by the end of the nineteenth century (Fraser 1910; Downey 1935; Sheppard et al. 2009). This is a likely explanation for the observed decrease in $\mathrm{Pb}$ and $\mathrm{Zn}$ contents in the uppermost sections of the principal cores. While some mines re-opened in a recent mining phase (post-1960), these days' tailings are confined by dams (Craw and Chappell 2000).

Although the observations clearly point to mining as the most likely trigger for the elevated $\mathrm{Zn}$ and $\mathrm{Pb}$ contents in the Firth of Thames sediments, it also might be impacted by other processes. These include volcanic eruptions, changes in source area, enhanced erosion in the catchment and urban runoff. As New Zealand, part of the Pacific ring of fire, is characterised by frequently occurring volcanic eruptions also over the last millennium (Lowe et al. 2002; Lowe 2008), the sudden increase in $\mathrm{Pb}$ and $\mathrm{Zn}$ records after low and rather constant inputs for seemingly centuries (Fig. 6) does not fit to a volcanic source of the heavy metals.

To link the enhanced $\mathrm{Pb}$ and $\mathrm{Zn}$ inputs to a change in source area would most likely also require changes in the sediment transport and deposition processes that should be reflected in the grain-size data. However, in the principal cores (except NZ-M-2), the grain-size compositions show no major change corresponding to the increase in heavy metal contents (Figs. 3 and 6). This is further supported by the macroscopic lithological core description of the remaining five cores, with sand sedimentation near the Waihou River mouth (NZ-M-3) and homogeneous silt grain sizes for all others (NZ-M-1, NZM-5, NZ-M-6, NZ-M-8).

Interestingly, the lowest $\mathrm{Pb}$ and $\mathrm{Zn}$ contents in the sanddominated lower part of core NZ-M-2 are comparable or only slightly above the 'background' values observed in the two other fine-grained principal cores (Figs. 3 and 6), despite any grain-size effect. However, the coarser grained deposits in this core might derive from a different source area. Still, natural background values for $\mathrm{Pb}(45 \mathrm{ppm})$ and $\mathrm{Zn}(101 \mathrm{ppm})$ recorded in NZ-M-2 for the Polynesian era are much higher than for cores NZ-M-4 and NZ-M-7 collected further offshore (Pb, 8 $12 \mathrm{ppm}$; Zn, 51-57 ppm). This offset might be due to the close proximity of core NZ-M-2 to the Thames gold deposits immediately onshore. A comparable short transport distance, thus, might have resulted in higher natural $\mathrm{Pb}$ and $\mathrm{Zn}$ inputs to this site originating from natural erosion.

The discussion, if erosion in New Zealand has increased after arrival of the first humans, is controversial (e.g. Grant 1985; McGlone 1989; Wilmshurst 1997; Ogden et al. 2003). Both, the Polynesian and the European settlers cleared vast stretches of land for agriculture. Nevertheless, on a regional scale around the Firth of Thames, the arrival of the Polynesians left no traces in the sediment composition (grains size, $\mathrm{Pb}$ and $\mathrm{Zn}$ contents) albeit sedimentation rates slightly increased (Table 3). Thus, deforestation by the Polynesians probably just mobilised more sediments from the same source area representative for the regional lithology by the same transport processes. The same can be assumed for the effects of forest clearances during the European era done in the context of farming, construction works, kauri logging and gum digging (Sale 1978; Hume and Dahm 1992). Consequently, these activities probably increased the quantity of the eroded sediments, but did not affect the composition towards containing more heavy metals. Thus, deforestation probably also had no major impact on the sudden increase of $\mathrm{Zn}$ and $\mathrm{Pb}$ inputs since the 1840s. Still, it has to be acknowledged that there is conflicting evidence in core NZ-M-2, where a distinct natural 
background value cannot be determined with absolute certainty due to a change in grain size.

Finally, also significant urban runoff from the major settlement areas on New Zealand's North Island was identified as a source for heavy metals. However, being documented to begin in the mid-1920s for Wellington Harbour (Dickinson et al. 1996) and post-1945 in the Tamaki Estuary (Auckland area; Abrahim and Parker 2002), urban runoff is not very likely to cause the sudden increase in $\mathrm{Pb}$ and $\mathrm{Zn}$ contents at c.1845 in the Firth of Thames that is surrounded by only lightly populated areas. In addition, by pinpointing the years around 1970 in the presented records by increasing Pinus spp. pollen numbers and by the occurrence of Olea europaea, heavy metal inputs to the Firth of Thames were already decreasing shortly after urban runoff began to affect the Auckland region. Based on these considerations, gold mining in the Coromandel Peninsula is most likely the dominant cause for an increased release of $\mathrm{Pb}$ and $\mathrm{Zn}$ during the European era.

\section{Assessment of human impact}

Based on the dated cores, it can be concluded that the onset of enhanced heavy metal input clearly observed in six out of the eight investigated cores from the Firth of Thames occurred at all sites simultaneously approximately at $1845 \mathrm{CE}$. Since then, enhanced heavy metal input, most likely due to historic gold mining in the region, had a widespread effect on sediment chemistry in the Firth of Thames. However, as the pXRF-based data are considered as less reliable, the heavy metal contents will be evaluated quantitatively only in the principal cores.

In the principal cores, the baseline contents for $\mathrm{Zn}$ and $\mathrm{Pb}$ are extremely stable in the pre-European era, suggesting that these reflect pristine natural background values. Except for NZ-M-2 where the natural baseline is not absolute certain, background values in the Firth of Thames are significantly lower than those
Table 5 ANZECC Sediment Quality Guideline Values for total content of lead and zinc

\begin{tabular}{llll}
\hline & $\mathrm{Pb}$ & $\mathrm{Zn}$ & Effects \\
\hline Category 1 & $<50 \mathrm{ppm}$ & $<200 \mathrm{ppm}$ & Negligible \\
Category 2 & $50-220 \mathrm{ppm}$ & $200-410 \mathrm{ppm}$ & Possible \\
Category 3 & $>220 \mathrm{ppm}$ & $>410 \mathrm{ppm}$ & Expected \\
\hline
\end{tabular}

reported for Wellington Harbour (Dickinson et al. 1996) and for the Tamaki Estuary near Auckland (Abrahim and Parker 2008) (Table 4). These differences in background values underline the need for baseline studies in different regions with different hydrological and geological settings.

According to the Australian and New Zealand Environment and Conservation Council (ANZECC) Sediment Quality Guidelines (Simpson et al. 2013), the $\mathrm{Pb}$ and $\mathrm{Zn}$ contents of the surface sediments are within the Sediment Quality Guideline Values (SQGV) Category 1 indicating negligible effects (Table 5). However, as all three cores show $\mathrm{Zn}$ and $\mathrm{Pb}$ peaks in the subsurface and decrease again towards the core top, Category 1 thresholds have been passed in the past. Taking the average peak values (Fig. 6, Table 4), the $\mathrm{Pb}$ contents of all three principal cores and the $\mathrm{Zn}$ contents of two of them fall into Category 2, meaning ecological effects are possible. Sediment contents of $\mathrm{Pb}$ and $\mathrm{Zn}$ belonging to SQGV Category 3 were not measured in either of the cores. While $\mathrm{Pb}$ and $\mathrm{Zn}$ contents in the surface sediments are below the threshold for Category 2, the higher contents in the subsurface impose potential threats for the ecosystem in case of resuspension. Although in the past natural processes (e.g. tides, storms) seemingly did not release these strongly polluted subsurface sediments, human activities such as, e.g. dredging and bottom trawling, indeed bear the risk to re-introduce these pollutants into the environment.

Considering the spatial-temporal pattern displayed being the pXRF data, it can be assumed that also for the wider area in the southeastern Firth of Thames in the subsurface
Table 4 XRF Scanner contents of $\mathrm{Pb}$ and $\mathrm{Zn}$ in ppm of the surface sediments (topmost value obtained in the sediment core), the averaged peak section (all values from peak onset to core top) and the averaged background section (all values below peak onset) measured on the three principal cores. Additionally $\mathrm{Pb}$ and $\mathrm{Zn}$ values for the Tamaki Estuary
(Abrahim and Parker 2008) and for Wellington Harbour (Dickinson et al. 1996) are listed for comparison. Values in parentheses present the conflicting potential natural baseline which are not comparable because of grain-size differences. $\mathrm{EF}=$ enrichment factor comparing peak average and background values

\begin{tabular}{|c|c|c|c|c|c|c|c|c|c|c|}
\hline & \multicolumn{2}{|l|}{ NZ-M-2 } & \multicolumn{2}{|l|}{ NZ-M-4 } & \multicolumn{2}{|l|}{ NZ-M-7 } & \multicolumn{2}{|c|}{ Abrahim and Parker (2008) } & \multicolumn{2}{|c|}{ Dickinson et al. (1996) } \\
\hline & $\mathrm{Pb}(\mathrm{ppm})$ & $\mathrm{Zn}(\mathrm{ppm})$ & $\mathrm{Pb}(\mathrm{ppm})$ & $\mathrm{Zn}(\mathrm{ppm})$ & $\mathrm{Pb}(\mathrm{ppm})$ & $\mathrm{Zn}(\mathrm{ppm})$ & $\mathrm{Pb}(\mathrm{ppm})$ & $\mathrm{Zn}(\mathrm{ppm})$ & $\mathrm{Pb}(\mathrm{ppm})$ & $\mathrm{Zn}(\mathrm{ppm})$ \\
\hline Surface Sediment & 38 & 127 & 42 & 143 & 32 & 109 & & & & \\
\hline Peak average & 100 & 235 & 82 & 236 & 52 & 154 & 73 & 207 & 104 & 221 \\
\hline Background & $45(14)$ & $101(65)$ & 12 & 57 & 8 & 51 & 22 & 72 & 37 & 128 \\
\hline $\mathrm{EF}$ & 2.2 & 2.3 & 6.8 & 4.1 & 6.5 & 3.0 & 3.3 & 2.9 & 3 & 1.7 \\
\hline
\end{tabular}


sediments Category 2 thresholds might be passed. To what extent the $\mathrm{Pb}$ and $\mathrm{Zn}$ signal can be detected also in the outer Firth of Thames and the bordering Hauraki Gulf is currently unknown. However, as the strongest signals occur near the Waihou River mouth and along the coast of the Coromandel Peninsula, which is rich in ore deposits (Livingston 1987), it is likely that enhanced heavy metal pollution can be traced along the entire western coast of the Coromandel Peninsula up to the Hauraki Gulf. With respect to the unique settlement history of New Zealand, it might be speculated that with the onset of the European Era also other near-coastal areas in the vicinity to New Zealand mining districts experienced heavy metal pollution similar to the Firth of Thames.

\section{Conclusion}

From the results presented the following conclusions can be drawn:

- In the Firth of Thames, a significant increase of $\mathrm{Pb}$ and $\mathrm{Zn}$ contents occurred with the onset of the European era.

- This increase was most likely caused by mining.

- The sedimentation rates during this time period increased simultaneously, but might not only be related to the historic gold mining operations.

- The impact on the $\mathrm{Pb}$ and $\mathrm{Zn}$ contents of the bulk sediment is widespread in the southeastern Firth of Thames.

- All Pb and Zn surface sediment contents are according to ANZECC within the Sed Quality Guideline Values for Category 1.

- Sedimentary $\mathrm{Pb}$ and $\mathrm{Zn}$ contents in the subsurface fall within ANZECC Sediment Quality Guideline Values Category 2 , posing a potential threat in case of resuspension.

Acknowledgements This project was funded by the Deutsche Forschungsgemeinschaft (DFG) through the International Research Training Group-'Integrated Coastal Zone and Shelf-Sea Research' (GRK 1598 INTERCOAST). Funding for radiometric dating was partly provided by Waikato Regional Council, New Zealand (Funding Deed No: SAS2017/2019-1955). The authors would like to thank Dean Sandwell and Christopher Morcom for the technical support during the coring campaign. Data were in parts acquired at the XRF Core Scanner $\mathrm{Lab}$ at the MARUM - Center for Marine Environmental Sciences, University of Bremen, Germany. The data reported in this paper will be archived in Pangaea (www.pangaea.de)

Open Access This article is distributed under the terms of the Creative Commons Attribution 4.0 International License (http:// creativecommons.org/licenses/by/4.0/), which permits unrestricted use, distribution, and reproduction in any medium, provided you give appropriate credit to the original author(s) and the source, provide a link to the Creative Commons license, and indicate if changes were made.

\section{References}

Abrahim G, Parker R (2002) Heavy metal contaminants in Tamaki Estuary: impact of city development and growth, Auckland, New Zealand. Environ Geol 42:883-890

Abrahim GMS, Parker RJ (2008) Assessment of heavy metal enrichment factors and the degree of contamination in marine sediments from Tamaki Estuary, Auckland, New Zealand. Environ Monit Assess 136(1):227-238

Adams CJ, Graham IJ, Seward D, Skinner DNB, Adams CJ, Skinner DNB, Moore PR (1994) Geochronological and geochemical evolution of late Cenozoic volcanism in the Coromandel Peninsula, New Zealand. N Z J Geol Geophys 37(3):359-379

Augustinus P, Reid M, Andersson S, Deng Y, Horrocks M (2006) Biological and geochemical record of anthropogenic impacts in recent sediments from Lake Pupuke, Auckland City, New Zealand. J Paleolimnol 35:789-805

Badr NBE, El-Fiky AA, Mostafa AR et al (2009) Metal pollution records in core sediments of some Red Sea coastal areas, Kingdom of Saudi Arabia. Environ Monit Assess 155:509-526

Blaauw M, van Geel B, Kristen I et al (2011) High-resolution 14C dating of a 25,000-year lake-sediment record from equatorial East Africa. Quat Sci Rev 30(21-22):3043-3059

Black KP, Bell RG, Oldman JW, Carter GS, Hume TS (2000) Features of 3 dimensional barotropic and baroclinic circulation in the Hauraki Gulf, New Zealand. N Z J Mar Freshw Res 34(1):1-28

Brathwaite RL, Cargill HJ, Christie AB, Swain A (2001) Lithological and spatial controls on the distribution of quartz veins in andesite- and rhyolite-hosted epithermal Au-Ag deposits of the Hauraki Goldfield, New Zealand. Mineral Deposita 36:1-12

Byrami M, Ogden J, Horrocks M, Deng Y, Shane P, Palmer J (2002) A palynological study of Polynesian and European effects on vegetation in Coromandel, New Zealand, showing the variability between four records from a single swamp. J R Soc N Z 32(3):507-531

Christie AB, Simpson MP, Brathwaite RL, Mauk JL, Simmons SF (2007) Epithermal Au-Ag and related deposits of the Hauraki Goldfield, Coromandel Volcanic Zone, New Zealand. Econ Geol 102:785-816

Clement AJ, Nováková T, Hudson-Edwards KA, Fuller IC, Macklin MG, Fox EG, Zapico I (2017) The environmental and geomorphical impacts of historical mining in the Ohinemuri and Waihou river catchments, Coromandel, New Zealand. Geomorphology 295:159-175

Craw D, Chappell DA (2000) Metal redistribution in historic mine wastes, Coromandel Peninsula, New Zealand. N Z J Geol Geophys 43(2):187-198

Dickinson WW, Dunbar GB, McLeod H (1996) Heavy metal history from cores in Wellington Harbour, New Zealand. Environ Geol 27:59-69

Downey JF (1935) Gold mines of the Hauraki district, New Zealand. Govt. Printer, Wellington N.Z.

Dredge M (2014) Natural hazard risk assessment for Matamata Piako District. Waikato Regional Council Technical Report 2014/01, Waikato Regional Council, Hamilton

Faegri K, Iversen J (1989) Textbook of pollen analysis, 4th edition. Wiley, Chichester

Förstner U, Wittmann GTW (1981) Metal pollution in the aquatic environment, 2nd edn. Springer, Berlin, pp 121-131

Fraser C (1910) The geology of the Thames subdivision, Hauraki, Auckland New Zealand Geological Survey Bulletin, 10

Fukue M, Nakamura T, Kato Y, Yamasaki S (1999) Degree of pollution for marine sediments. Eng Geol 53(2):131-137

Garrels RM, Thompson ME (1960) Oxidation of pyrite in iron sulfate solutions. Am J Sci 258A:57-67

Grant PJ (1985) Major periods of erosion and alluvial sedimentation in New Zealand during the late Holocene. J R Soc N Z 15(1):67-121 
Hebbeln D, Scheurle C, Lamy F (2003) Depositional history of the Helgoland mud area, German Bight, North Sea. Geo-Mar Lett 23(2):81-90

Heenan PB, de Lange PJ, Glenny DS, Breitwieser I, Brownsey PJ, Ogle CC (1999) Checklist of dicotyledons, gymnosperms, and pteridophytes naturalised or casual in New Zealand: Additional records 1997-1998. N Z J Bot 37(4):629-642

Hicks D, Shankar U, McKerchar A, Basher L, Jessen M, Lynn I, Page M (2011) Suspended sediment yields from New Zealand rivers. J Hydrol N Z 50(1):81-142

Hirabayashi S, Yokoyama Y, Suzuki A, Miyairi Y, Aze T (2017) Multidecadal oceanographic changes in the western Pacific detected through high-resolution bomb-derived radiocarbon measurements on corals. Geochem Geophys Geosyst 18(4):1608-1617

Hochstein MP, Nixon IM (1979) Geophysical study of the Hauraki Depression, North Island, New Zealand. N Z J Geol Geophys 22(1):1-19

Horrocks M, Deng Y, Ogden J, Alloway BV, Nichol SL, Sutton DG (2001) High spatial resolution of pollen and charcoal in relation to the c. 600 yr B.P. Kaharoa Tephra: implications for Polynesian settlement of Great Barrier Island, northern New Zealand. J Archaeol Sci 28:153-168

Hume TM, Dahm J (1992) An investigation of the effects of Polynesian and European land use on sedimentation in Coromandel Estuaries. Prepared for the Department of Conservation, Hamilton Regional Office

Irion G, Wunderlich F, Schwedhelm E (1987) Transport of clay minerals and anthropogenic compounds into the German Bight and the provenance of fine-grained sediments SE of Helgoland. J Geol Soc Lond 144(1):153-160

Ishizawa T, Goto K, Yokoyama Y, Miyairi Y, Sawada C, Nishimura Y, Sugawara D (2017) Sequential radiocarbon measurement of bulk peat for high-precision dating of tsunami deposits. Quat Geochronol 41:202-210

Jansen JHF, Van Der Gaast SJ, Koster B, Vaars AJ (1998) CORTEX, a shipboard XRF-scanner for element analyses in split sediment cores. Mar Geol 151(1-4):143-153

Kidd CH (1988) Prediction of solute transport from gold mine wastes, Coromandel, New Zealand. Proc 3rd Intl Mine Water Conf, Melbourne, Australia, pp 173-184

Kido Y, Koshikawa T, Tada R (2006) Rapid and quantitative major element analysis method for wet fine-grained sediments using an XRF microscanner. Mar Geol 229(3-4):209-225

Leblanc M, Morales JA, Borrego J, Elbaz-Poulichet F (2000) 4,500-yearold mining pollution in southwestern Spain: long-term implications for modern mining pollution. Econ Geol 95(3):655-662

Livingston ME (ed) (1987) Preliminary studies on the effects of past mining on the aquatic environment, Coromandel Peninsula Water \& Soil Miscellaneous Publication Number 104.

Lowe DJ (2008) Polynesian settlement of New Zealand and the impacts of volcanism on early Maori society: an update. In: Lowe DJ (ed) Guidebook for Pre-conference North Island Field Trip A1 'Ashes and Issues' (28-30 November, 2008). Australian and New Zealand 4th Joint Soils Conference, Massey University, Palmerston North (1-5 Dec. 2008). New Zealand Society of Soil Science, 142-147

Lowe DJ, Newnham RM, McCraw JD (2002) Volcanism and early Maori society in New Zealand. In: Torrence R, Grattan J (eds) Natural Disasters and Cultural Change. Routledge, London, pp 126-161

McFadgen BG (1994) Coastal stratigraphic evidence for human settlement. In: Sutton DG (ed) The Origins of the First New Zealanders. Auckland University Press, Auckland, pp 195-207

McGlone MS (1983) Polynesian deforestation of New Zealand: a preliminary synthesis. Archaeol Ocean 18:1-10
McGlone MS (1989) The polynesian settlements of New Zealand in relation to environmental and biotic changes. $\mathrm{N} \mathrm{Z} \mathrm{J} \mathrm{Ecol}$ 12:115-129

McGlone MS, Wilmshurst JM (1999) Dating initial Maori environmental impact in New Zealand. Quat Int 59:5-16

McGlone MS, Anderson AJ, Holdaway RN (1994) An ecological approach to the settlement of New Zealand. In: Sutton DG (ed) The Origins of the First New Zealanders. Auckland University Press, Auckland, pp 136-163

McGregor HV, Dupont L, Stuut J-BW, Kuhlmann H (2009) Vegetation change, goats, and religion: a 2000-year history of land use in southern Morocco. Quat Sci Rev 28:1434-1448

Naish TR (1990) Late Holocene mud sedimentation and diagenesis in the Firth of Thames: bentonite in the making. M.Sc. Thesis, Univ. Waikato, New Zealand.

Naish TR, Nelson CS, Hodder APW (1993) Evolution of Holocene sedimentary bentonite in a shallow-marine embayment, Firth of Thames, New Zealand. Mar Geol 109:267-278

Newnham RM, de Lange PJ, Lowe DJ (1995a) Holocene, vegetation, climate and history of a raised bog complex, northern New Zealand based on palynology, plant macrofossils and tephrochronology. The Holocene 5:262-282

Newnham RM, Lowe DJ, Wigley GNA (1995b) Late Holocene palynology and palaeovegetation of tephra-bearing mires at Papamoa and Waihi Beach, western Bay of Plenty, North Island, New Zealand. J R Soc N Z 25:283-300

Newnham RM, Lowe DJ, McGlone MS, Wilmshurst JM, Higham TFG (1998) The Kaharoa tephra as a critical datum for earliest human impact in northern New Zealand. J Archaeol Sci 25(6):533-544

Newnham R, Lowe DJ, Gehrels M, Augustinius P (2018) Two-step human-environmental impact history for northern New Zealand linked to late-Holocene climate change. The Holocene 00:1-14

Ogden J, Basher L, McGlone M (1998) Fire, forest regeneration and links with early human habitation: evidence from New Zealand. Ann Bot 81:687-696

Ogden J, Deng Y, Boswijk G, Sandiford A (2003) Vegetation changes since early Maori fires in Waipoua Forest, Northern New Zealand. J Archaeol Sci 30(6):753-767

Reimer PJ, Bard E, Bayliss A et al (2013) IntCal13 and Marine13 radiocarbon age calibration curves $0-50,000$ Years cal BP. Radiocarbon 55(4):1869-1887

Sale EV (1978) Quest for the kauri: forest giants and where to find them. Reed, Wellington

Seshan BRR, Natesan U, Deepthi K (2010) Geochemical and statistical approach for evaluation of heavy metal pollution in core sediments in southeast coast of India. Int J Environ Sci Technol 7(2):291-306

Sheppard DS, Christie AB, Goff J, Carver R (2009) Stream sediment geochemical survey in an area of volcanic-hosted epithermal Au$\mathrm{Ag}-\mathrm{Zn}-\mathrm{Pb}-\mathrm{Cu}$ deposits and porphyry $\mathrm{Cu}$ prospects, Thames, Coromandel Peninsula, New Zealand. Geochem-Explor Env A 9(3):279-296

Simpson SL, Batley GE, Chariton AA (2013) Revision of the ANZECC/ ARMCANZ Sediment Quality Guidelines. CSIRO Land and Water Science Report 08/07, CSIRO Land and Water

Stuiver M, Reimer PJ, Braziunas TF (1998) High-precision radiocarbon age calibration for terrestrial and marine samples. Radiocarbon 40(3):1127-1151

Stuiver M, Reimer PJ, Reimer RW (2018) CALIB 7.1 [WWW program] at http://calib.org

Tjallingii R, Röhl U, Kölling M, Bickert T (2007) Influence of the water content on X-ray fluorescence corescanning measurements in soft marine sediments. Geochem Geophys Geosyst 8(2):1-12

Webster JG (1995) Chemical processes affecting trace metal transport in the Waihou River and estuary, New Zealand. N Z J Mar Freshw Res 29(4):539-553 
Williams GJ (1974) Economic geology of New Zealand: the TJ McKee memorial volume. (McKee TJ, NZG Survey, Eds) ([2nd ed.]). Australasian Institute of Mining and Metallurgy, Parkville, Australia

Wilmshurst JM (1997) The impact of human settlement on vegetation and soil stability in Hawke's Bay, New Zealand. N Z J Bot 35(1):97-111

Yokoyama Y, Miyairi Y, Matsuzaki H, Tsunomori F (2007) Relation between acid dissolution time in the vacuum test tube and time required for graphitization for AMS target preparation. Nucl Inst Methods Phys Res B 259:330-334
Yokoyama Y, Koizumi M, Matsuzaki H, Miyairi Y, Ohkouchi N (2010) Developing ultra small-scale radiocarbon sample measurement at the University of Tokyo. Radiocarbon 52:310-318

Young KE, Evans CA, Hodges KV, Bleacher JE, Graff TG (2016) A review of the handheld X-ray fluorescence spectrometer as a tool for field geologic investigations on Earth and in planetary surface exploration. Appl Geochem 72:77-87

Publisher's note Springer Nature remains neutral with regard to jurisdictional claims in published maps and institutional affiliations. 